\title{
ANALYSIS OF LIPOPHILIC FRACTION OF THE COMMON PUSSYTOES HERB
}

Introduction. The lipophilic fractions of many medicinal plants are poorly understood today, despite the fact that they contain such important biologically active substances as chlorophylls, carotenoids, tocopherols, phytosterols, fatty acids, phospholipids, etc., which according to the literature show reparative, anti-inflammatory, antiseptic, immunostimulant, antitumor activity. Compounds of lipophilic nature are carotenoids and chlorophylls are of great importance. Carotenoids increase the body's resistance to mutagens and carcinogens, reduce age-related degenerative changes in tissues, inhibit proliferation of malignant cells, activate the synthesis of cytokines and interleukins, participate in the regulation of gene transcription, and also exhibit immunomodulatory effects. The antioxidant properties of carotenoids cause their photo-protective, radioprotective, anti-mutagenic and anti-carcinogenic effects. Chlorophyll in the human body promotes the formation of hemoglobin and can be used in medicine as a valuable therapeutic agent that accelerates the processes of hematopoiesis, affects the blood's formula, as well as stabilizes the functioning of the circulatory system. It has the ability to activate various functions of the human body, in particular thyroid gland, antitoxic function of the liver, as well as a tonic, normalizes metabolic processes and improves immunity.

The aim of the study - to obtain a lipophilic extract from the herb of the common pussytoes, to study its qualitative composition and to determine the quantitative content of carotenoids and chlorophylls.

Research Methods. The lipophilic fraction from the common pussytoes herb was maintained by the way of exhausting extraction of the raw materials chloroform in the Sockslet apparatus. The obtained lipophilic fraction was used for the determination of chlorophylls and carotenoids. The definitions are followed by the TLC method. Determination of the quantitative content of chlorophylls and carotenoids was carried out by spectrophotometric method. Content of the amount of chlorophylls was determined at $670 \mathrm{~nm}$ in terms of chlorophyll A; carotinoids - for the benefit of a wave of $450 \mathrm{~nm}$, based on $\beta$-carotene.

Results and Discussion. The results of the studies showed that the yield of the lipophilic fractions of the common pussytoes herb was equal to the absolute dry material $(6.17 \pm 0.12) \%$. Lipophilic fraction of the common pussytoes herb is a thick butter indiscrete mass of dirty-green color with a pleasant specific odor; practically insoluble in water purified $P$ and ethanol $96 \% P$, readily soluble in chlorophyll $P$. The content of chlorophylls and carotenoids in the investigated extract was $(0.085 \pm 0.003) \%$ and $(0.029 \pm 0.001) \%$. The content of chlorophylls in the common pussycat herb was 2.9 times higher than carotenoids.

Conclusions. The lipophilic fraction of the common pussytoes herb was obtained, the output of which was $6.17 \%$. In the lipophilic fraction, the quantitative content of chlorophylls and carotenoids was determined, which was in the common pussytoes herb $0.085 \%$ and $0.029 \%$, respectively.

KEY WORDS: common pussytoes; lipophilic fraction; carotenoids; chlorophylls.

INTRODUCTION. Plants are one of the sources of obtaining biologically active substances that exhibit diverse pharmacological activity and, on the basis of which many medicines are created.

The lipophilic fractions of many medicinal plants remain under-investigated, despite the fact that they contain such important biologically active substances as chlorophylls, carotenoids, tocopherols, phytosterols, fatty acids, phospholipids, etc., which according to the literature show reparative, antiinflammatory, antiseptic, immunostimulant, antitumor activity [1-4]. Compounds of lipophilic nature are carotenoids and chlorophylls, which belong to (c) R. Yu. Basaraba, S. M. Marchyshyn, M. V. Kyryliv, I. R. Bekus, 2019. the leading place in the process of photosynthesis of plants are of great importance. Chlorophylls are involved in the formation of the structure of the photosynthetic apparatus, play an important role in photosynthetic and photochemical reactions. Carotenoids - polyfunctional pigments that play the role of auxiliary luminous pigments in the process of photosynthesis, protect chlorophyll from destruction during oxidative stress caused by unfavorable environmental factors [5].

Carotenoids and chlorophylls are involved in the physiological processes that occur in the human body, in biochemical reactions occurring in cells of the human body [6]. 
It is known that carotenoids increase the body's resistance to mutagens and carcinogens [7], reduce age-related degenerative changes in tissues, inhibit the proliferation of malignant cells [8], activate the synthesis of cytokines and interleukins [9], participate in the regulation of gene transcription, and also exhibit immunomodulatory action [6]. Epidemiological studies showed that a reduction in the consumption or absorption of carotenoids increases the risk of cancer, cataracts, cardiovascular and other diseases $[6,10]$. The antioxidant properties of carotenoids cause their photo-protective, radioprotective, anti-mutagenic and anti-carcinogenic effects [6, 11, 12].

The physiological effect of chlorophylls on the human body is less studied than the effect of carotenoids. But, clinical trials showed [13] that chlorophyll in the human body promotes the formation of hemoglobin and can be used in medicine as a valuable therapeutic agent that accelerates the processes of hematopoiesis, affects the blood's formula, and stabilizes the functioning of the circulatory system.

Information regarding the provitamin activity of chlorophylls (provitamin K) [14], which determines its use for the prevention of urolithiasis, as it inhibits the formation of calcium oxalate crystals in urine, is confirmed [15]. In addition, chlorophylls have the ability to activate various functions of the human body, in particular thyroid gland, antitoxic function of the liver, as well as a tonic drug, normalize metabolic processes and increase immunity. In addition, chlorophylls are able to prevent pathological changes in DNA molecules, remove toxins from the body, improve the functioning of the intestine $[13$, $14,16]$.

The aim of the study - to obtain a lipophilic extract from the herb of the common pussytoes, to study its qualitative composition and to determine the quantitative content of carotenoids and chlorophylls.

RESEARCH METHODS. The lipophilic fraction from the herb of the common pussytoes was obtained by the comprehensive extraction of the raw material $(3.0 \mathrm{~g})$ with chloroform in the Soxhlet apparatus. Extraction lasted until the absolute depletion of the raw material. The resulting chloroform extract after absolute depletion of the solvent was dried at $95^{\circ} \mathrm{C}$ to constant mass, cooled and weighed on analytical scales.

The content of lipophilic substances, in terms of absolute dry substance, in percentages, was counted according to the following formula:

$$
\mathrm{X}=\frac{(\mathrm{a}-\mathrm{b}) \cdot 100 \cdot 100}{\mathrm{~m} \cdot(100-W)},
$$

where: $\mathrm{a}$ - weight of the boiling flask with dry lipophilic fraction, $\mathrm{g}$; $\mathrm{b}$ - weight of an empty boiling flask, $\mathrm{g}$;

$\mathrm{m}$ - weight of the raw material sample weight, $\mathrm{g}$;

$\mathrm{W}$ - loss in weight when drying the raw material, \% [17].

The obtained lipophilic fraction was used for the determination of chlorophylls and carotenoids. The definitions are followed by the method of TLC in the solvent system: direction I - hexane $P$ - acetone $P$ (6:2); direction II - hexane $P$ - acetone $P$ (6:4). Chromatographic plates of Sorbfil (Sorbfil plates $10 \times 15$, Russia) were used.

The localization of chlorophylls on chromatograms was determined by green color in visible light, and in UV light - by bright-red fluorescence. The presence of carotenoids was determined by the yellow-orange colouring spots in visible light and the brown fluorescence of UV-stained spots $(\lambda=366 \mathrm{~nm})$ [17].

Determination of the quantitative content of chlorophylls. $0.05 \mathrm{~g}$ (current weight) of the lipophilic fraction was dissolved in $50 \mathrm{ml}$ of $P$ chloroform. The optic density of the obtained solution was measured at a wave length of $670 \mathrm{~nm}$ in a cuvet with a thickness of $10 \mathrm{~mm}$. The solution of chloroform $P$ was used as a solution of comparison.

The content of the amount of chlorophylls in terms of chlorophyll A, in percentage, was calculated by the formula:

$$
X=\frac{10 \cdot A \cdot 50}{A_{1}^{1 \%} \cdot m},
$$

where: 10 - content of chlorophyll A in $1 \mathrm{ml} 1 \%$ of solution, $\mathrm{mg}$;

A - optical density of the investigated solution;

$\mathrm{m}$ - sample weight, g;

$\mathrm{A}_{1}^{1} \%$ cm -specific absorption index of chlorophyll A at a wavelength of $670 \mathrm{~nm}-944.5$ [18].

Determination of the quantitative content of carotenoids. Quantitative content of carotenoids was determined by spectrophotometric method. $0.05 \mathrm{~g}$ (current sample weight) of the lipophilic fraction was dissolved in $50 \mathrm{ml}$ of $P$. The optical density of the obtained solution was measured at a wavelength of $450 \mathrm{~nm}$ in a cuvette with a $10 \mathrm{~mm}$ of layer thickness. As a solution, the solution of chlorophyll $P$. was used.

The content of carotenoids in terms of $\beta$-carotene, in percentages, was calculated by the formula:

$$
X=\frac{10 \cdot A \cdot 50}{A_{1 \mathrm{~cm}}^{1 \%} \cdot \mathrm{m}},
$$

where: 10 - content of $\beta$-carotene in $1 \mathrm{ml}$ of $1 \%$ solution, mg;

A - optical density of the studied solution;

$\mathrm{m}$ - sample weight, g;

$A_{1}^{1 \%} \mathrm{~cm}$ - specific absorption rate of $\beta$-carotene at $450 \mathrm{~nm}$ wavelength -2400 [18]. 
RESULTS AND DISCUSSION. The results of the studies showed that the yield of the lipophilic fractions of the herb of the common pussytoes was equal to the absolute dry material $(6.17 \pm 0.12) \%$.

Lipophilic fraction of the common pussytoes herb - a thick oily indiscrete mass of dirty-green color with a pleasant specific odor; practically un- solvable in the purified $P$ water and ethanol $96 \%$ $P$, freely soluble in chloroforms $P$.

The obtained lipophilic fraction of the common pussytoes herb was used to determine the chlorophylls and carotenoids by the TLC method in the solvent systems: direction I: hexane $P$ - acetone $P$ (6:2); direction II - hexane $P$ - acetone $P$ (6:4) (Fig. 1 and 2).

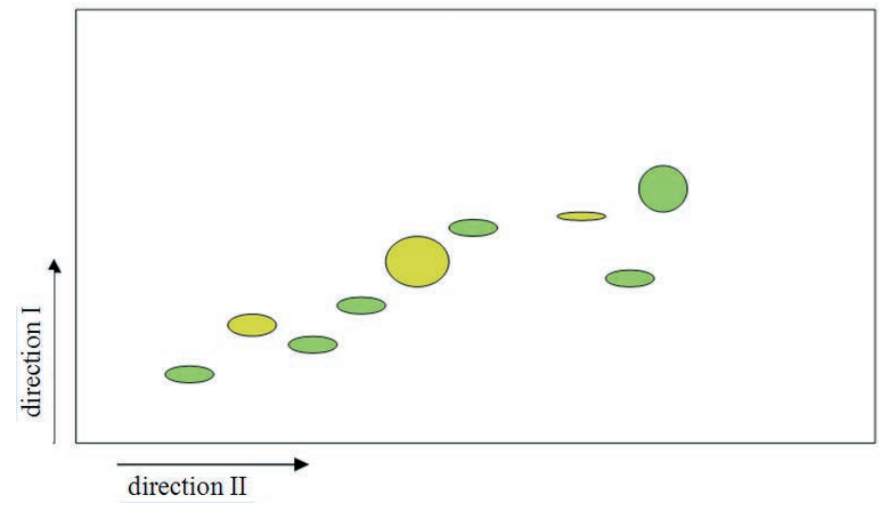

Fig. 1. TLC-chromatogram of the lipophilic fraction of the common pussytoes herb in visible light. Chromatographic plates of the Sorbfil brand (Sorbfil plates 10x15, Russia). Solvent system: direction I- hexane $P$ - acetone $P(6: 2)$; direction II - hexane $P$ - acetone $P$ (6:4).

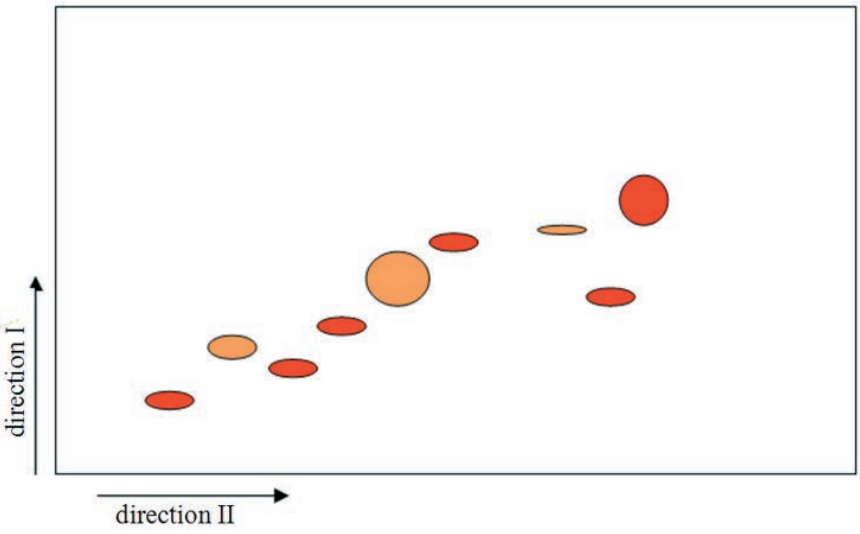

Fig. 2. TLC-chromatogram of the lipophilic fraction of the common pussytoes in the UV-light. Chromatographic plates of the Sorbfil brand (Sorbfil plates 10x15, Russia). Solvent system: direction I - hexane $P$ - acetone $P(6: 2)$; direction II - hexane $P$ - acetone $P(6: 4)$.

Determination of the quantitative content of chlorophylls and carotenoids in the lipophilic extract of the common pussytoes herb was carried out by spectrophotometric method. The content of chlorophylls and carotenoids in the investigated extract was $(0.085 \pm 0.003) \%$ and $(0.029 \pm 0.001) \%$. The results of the studies are presented in Figure 3.

CONCLUSIONS. 1. The lipophilic fraction of the common pussytoes herb was obtained, its output was $6.17 \%$.

2. The quantitative content of chlorophylls and carotenoids, which was in the common pussytoes herb $0.085 \%$ and $0.029 \%$, respectively, was determined.

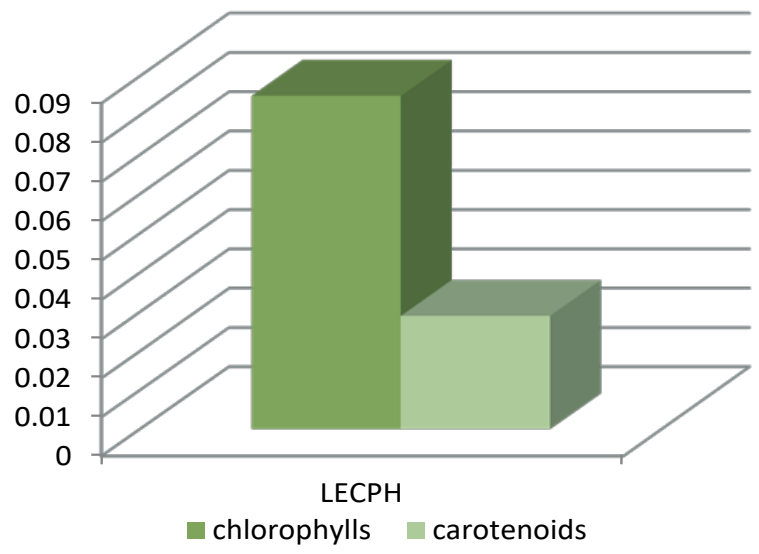

Fig. 3. The content of chlorophylls and carotenoids in the lipophilic extract of the common pussytoes herb The content of chlorophylls in the common pussytoes herb was 2.9 times higher than carotenoids. 


\section{LITERATURE}

1. Оптимізація технології екстракції ліпофрільних комплексів з лікарської рослинної сировини. 1. Вибір екстрагенту / С. В. Гарна, П. П. Ветров, О. І. Русинов, В. А. Геогріянц // Запорож. мед. журн. - 2010. - 12 № 3. - C. 92-94.

2. Ковалев С. В. Химическое исследование липосрильной фрракции травы люцерны серповидной / С. В. Ковалев // Запорож. мед. журн. - 2013. № 3 (78). - С. 94-97.

3. Марчишин С. М. Дослідження ліпофрільної фрракції трави перстачу гусячого (Potentilla anserina L.) / С. М. Марчишин, О. Б. Амброзюк// Мед. хімія. -2011. 13, № 3 (48). - С. 96-99.

4. Гарник Т. П. Обзор официнального и перспективного лекарственного растительного сырья / Т. П. Гарник, И. Л. Вихтинская, Т. И. Исакова // Фитотерапия в Украине. - 1998. - № 1. - С. 10-11.

5. Мальцева Н. М. Вплив біологічно активних речовин та їх композицій на вміст оротосинтетичних пігментів у листках озимої пшениці в умовах десріциту фросфрору / Н. М. Мальцева, А. П. Гаєвський, К. Ю. Дерев'янко // Физиология и биохимия культурных растений. - 2011. - 43, № 5. - С. 4403-411.

6. Сімонова М. Каротиноїди: будова, властивості та біологічна дія / М. Сімонова // Біологічні Студії/Studia Biologica. - 2010. - 4, № 2. - C. 159-170.

7. Ляхович В. В. Активная защита при окислительном стрессе. Антиоксидант-респонсивный элемент / В. В. Ляхович, В. А. Вавилин, Н. К. Зенков // Биохимия. - 2006. - № 71 (9). - С. 1183-1197.

8. Antitumor activity of astaxanthin and its mode of action / H. Jyonouchi, S. Sun, R. lijima [et al.] // Nutr. Cancer. - 2000. - No. 36 (1). - P. 59-65.

9. Dual effects of antioxidants in neurodegeneration: direct neuroprotection against oxidative stress and indi- rect protection via suppression of glia-mediated inflammation / J. Y. Wang, L. L. Wen, Y. N. Huang [et al.] // Curr. Pharm. Des. - 2006. - No. 12 (27). - P. 3521-3533.

10. Krinsky N. I. Carotenoid actions and their relation to health and disease / N. I. Krinsky, E. J. Johnson // Mol. Aspects Med. - 2005. - No. 26 (6). - P. 459-516.

11. Carotenoids and cardiovascular health / S. Voutilainen, T. Nurmi, J. Mursu [et al.] // Am. J. Clin. Nutr. 2006. - No. 83 (6). - P. 1265-1271.

12. Olson J. A. Carotenoids, vitamin A and cancer / J. A. Olson // J. Nutr. -1986. - No. 116 (6). -P. 1127-1130.

13. Chwiej M. Studia i opracowanie metody oraz zalozen technologiczno-projecto-wych do wydobycia likopenu z odpadow pomidorowych / M. Chwiej. Warszawa; 1983. - $167 \mathrm{p}$

14. Counsen J. N. Some of natures's food colourscarotenoids and ribofla-vins / J. N. Counsen, C. J. Kneustubb // Food Flavour., Clnged. Process. and Packag. 1983. - 5, No. 8. - P. 18-19.

15. Мерзлова Г. В. Вміст хлорофрілу у біомасі спіруліни за дії різних доз мікроелементів у поживному середовищі / Г. В. Мерзлова // Біологія тварин. 2014. - 16, № 2. - С. 71-76.

16. Пігменти. Хімічна природа [Електронний ресурс] // Короткий довідник біологічно активних речовин: Пігменти. - Режим доступу : http://beclan.org/ practical/rechovin_pgmenti.htm.

17. Тернинко І. І. Вивчення ліпофрільних комплексів трави та зерна вівса посівного (Avena sativa L.) / І. І. Тернинко, О. В. Бурцева // Фармац. журн. - 2010. № 1. - С. 89-95.

18. Марчишин С. М. Пігментний склад ліпофрільної срракції трави золототисячника звичайного / С. М. Марчишин, Л. І. Стойко // Укр. біофармац. журн. - 2015. № 1. - С. $65-68$.

\section{REFERENCES}

1. Harna, S.V., Vetrov, P.P., Rusynov, O.I., \& Heorhiiants, V.A. (2011). Optymizatsiia tekhnolohii ekstraktsii lipofilnykh kompleksiv z likarskoi roslynnoi syrovyny. 1. Vybir ekstrahentu [Optimization of the technology of extraction of lipophilic complexes from the medicinal plant raw materials. 1. Selection of extractant]. Zaporozhskiy meditsinskiy zhurnal - Zaporizhzhia Medical Journal, 12 (3), 92-94 [in Ukrainian].

2. Kovalev, S.V. (2013). Khimicheskoe issledovanie lipofilnoy fraktsii travy lyutserny serpovidnoy [Chemical study of the lipophilic fraction of alfalfa sickle grass]. Zaporozhskiy meditsinskiy zhurnal - Zaporizhzhia Medical Journal, 3 (78), 94-97 [in Russian].

3. Marchyshyn, S.M., \& Ambroziuk, O.B. (2011). Doslidzhennia lipofilnoi fraktsii travy perstachu husiachoho (Potentilla anserina L.) [Investigation of the lipophilic fraction of the silverweed cinquefoil herb (Potentilla anserina L.)]. Medychna khimiia - Medical Chemistry, 13 (3), 96-99 [in Ukrainian].
4. Harnyk, T.P., Vikhtinskaya, I.L., \& Isakova, T.I. (1998). Obzor ofitsialnogo i perspektivnogo lekarstvennogo rastitelnogo syrya [Overview of officinal and promising medicinal plant materials]. Fitoterapiya v Ukraine Phytotherapy in Ukraine, 1, 10-11 [in Russian].

5. Maltseva, N.M., Haievskyi, A.P., \& Derevianko, K.Yu. (2011). Vplyv biolohichno aktyvnykh rechovyn ta yikh komposytsii na vmist fotosyntetychnykh pihmentiv u lystkakh ozymoi pshenytsi v umovakh defitsytu fosforu [Influence of biologically active substances and their compositions on the content of photosynthetic pigments in leaves of winter wheat under conditions of phosphorus deficiency]. Fiziologiya i biokhimiya kult. rasteniy Physiology and Biochemistry of Cultivated Plants, 43 (5), 4403-411.

6. Simonova, M. (2010). Karotynoidy: budova, vlastyvosti ta biolohichna diia. Biolohichni studii [Carotenoids: structure, properties and biological effects. Biological Studios]. Studia Biologica, 4 (2), 159-170 [in Ukrainian]. 
7. Lyakhovych, V.V., Vavilin, V.A., \& Zenkov, N.K. (2006). Aktivnaya zashchita pri okislitelnom sresse. Antioksidant-responsivnyy element [Active protection with oxidative stress. Antioxidant-resisting element]. Biokhimiya - Biochemistry, 71 (9), 1183-1197 [in Russian].

8. Jyonouchi, H., Sun, S., lijima, K., \& Myron D. Gross (2000). Antitumor activity of astaxanthin and its mode of action. Nutr. Cancer, 36 (1), 59-65.

9. Wang, J.Y., Wen, L.L., \& Huang, Y.N., Chen, Y.T., \& Ku, M.C. (2006). Dual effects of antioxidants in neurodegeneration: direct neuroprotection against oxidative stress and indirect protection via suppression of gliamediated inflammation. Curr. Pharm. Des., 12 (27), 3521-3533.

10. Krinsky, N. I., \& Johnson, E.J. (2005). Carotenoid actions and their relation to health and disease. Mol. Aspects Med., 26 (6), 459-516.

11. Voutilainen, S., Nurmi, T., Mursu, J., \& Rissanen, T.H. (2006). Carotenoids and cardiovascular health. Am. J. Clin. Nutr., 83 (6), 1265-1271.

12. Olson, J.A. (1986). Carotenoids, vitamin A and cancer. J. Nutr., 116 (6), 1127-1130.

13. Chwiej, M. (1983). Studia i opracowanie metody oraz zalozen technologiczno-projecto-wych do wydobycia likopenu z odpadow pomidorowych. Warszawa.

14. Counsen, J.N., \& Kneustubb, C.J. (1983). Some of natures's food colours-carotenoids and ribofla-vins.
Food Flavour., Clnged. Process. and Packag., 5 (8), 18-19.

15. Merzlova, H.V. (2014). Vmist khlorofilu u biomasi spiruliny za dii riznykh doz mikroelementiv u pozhyvnomu seredovyshchi [The content of chlorophyll in biomass spirulina for the effects of various doses of trace elements in the nutrient medium]. Biolohiia tvaryn - Biology of Animals, 16 (2), 71-76 [in Ukrainian].

16. Pihmenty. Khimichna pryroda [Pigments. Chemical nature]. [Electronic resource] Korotkyi dovidnyk biolohichno aktyvnykh rechovyn: Pihmenty - Short guide to biologically active substances: Pigments. Retrieved from: http://beclan.org/practical/rechovin_pgmenti.htm [in Ukrainian].

17. Ternynko, I.I., \& Burtseva, O.V. (2010). Vyvchennia lipofilnykh kompleksiv travy ta zerna vivsa posivnoho (Avena sativa L.) [Study of lipophilic complexes of herb and grains of oat seeding (Avena sativa L.)]. Farmatsevtychnyi zhurnal - Pharmaceutical Journal, 1, 89-95 [in Ukrainian].

18. Marchyshyn, S.M., \& Stoiko, L.I. (2015). Pihmentnyi sklad lipofilnoi fraktsii travy zolototysiachnyka zvychainoho [The pigment composition of the lipophilic fraction of the herb of the common centaury]. Ukrainskyi biofarmatsevtychnyi zhurnal - Ukrainian Biopharmaceutical Journal, 1, 65-68 [in Ukrainian].

\section{АНАЛІЗ ЛІПОФІЛЬНОЇ ФРАКЦІЇ ТРАВИ КОТЯЧИХ ЛАПОК ДВОДОМНИХ}

\section{Резюме}

Вступ. Ліпофрільні фрракції багатьох лікарських рослин на сьогодні мало вивчено, незважаючи на те, що вони містять такі важливі біологічно активні речовини, як хлорофріли, каротиноїди, токофрероли, фрітостероли, жирні кислоти, фросфроліпіди та ін., які, за даними літератури, проявляють репаративну, протизапальну, антисептичну, імуностимулювальну, протипухлинну активність. Зі сполук ліпофрільної природи важливе значення мають каротиноїди і хлорофріли. Каротиноїди підвищують резистентність організму до мутагенів і канцерогенів, зменшують вікові дегенеративні зміни у тканинах, інгібують проліферацію злоякісних клітин, активують синтез цитокінів та інтерлейкінів, беруть участь у регуляціі транскрипції генів, а також проявляють імуномодулюючу дію. Антиоксидантні властивості каротиноїдів зумовлюють їх фротозахисну, радіопротекторну, антимутагенну й антиканцерогенну дію. Хлорофріли в організмі людини сприяють утворенню гемоглобіну. Їх можна застосовувати в медицині як цінний терапевтичний засіб, що прискорює процеси кровотворення. Вони впливають на фрормулу крові, а також стабілізують роботу кровоносної системи. Хлорофріли здатні активізувати різні фрункції організму людини, зокрема щитоподібної залози, антитоксичну фуннкцію печінки, а також є тонізуючим засобом, нормалізують метаболічні процеси та підвищують імунітет.

Мета дослідження - одержати ліпофрільний екстракт трави котячих лапок дводомних, вивчити його якісний склад та визначити кількісний вміст каротиноїдів і хлорофрілів.

методи дослідження. Ліпофрільну фрракцію трави котячих лапок дводомних одержували методом вичерпного екстрагування сировини хлорофрормом в апараті Сокслета. Отриману ліпофрільну фрракцію використовували для визначення хлорофрілів і каротиноїдів методом тонкошарової хроматографрії. Кількісний їх вміст визначали спектрофротометричним методом. Вміст суми хлорофрілів визначали при довжині хвилі 670 нм у перерахунку на хлорофріл А, каротиноїдів - при довжині хвилі 450 нм у перерахунку на $\beta$-каротин. 
Результати й обговорення. Вихід ліпофрільної фракції трави котячих лапок дводомних у перерахунку на абсолютно суху сировину становив $(6,17 \pm 0,12)$ \%. Ліпофрільна фрракція трави котячих лапок дводомних - густа масляниста однорідна маса брудно-зеленого кольору з приємним специфічним запахом, не розчиняється у воді очищеній Р та етанолі 96 \% Р, легко розчиняється у хлороформі Р. Вміст хлорофрілів і каротиноїдів у досліджуваному екстракті становив $(0,085 \pm 0,003)$ та $(0,029 \pm 0,001) \%$. Вміст хлорофрілів у траві котячих лапок дводомних був у 2,9 раза більшим, ніж каротиноїдів.

Висновки. Одержано ліпофрільну фракцію трави котячих лапок дводомних, вихід якої становив 6,17 \%. Визначено в ній кількісний вміст хлорофрілів і каротиноїдів, який становив у траві котячих лапок дводомних 0,085 та 0,029 \% відповідно.

КЛЮЧОВІ СЛОВА: котячі лапки дводомні; ліпофрільна фракція; каротиноїди; хлорофіли.

Р. Ю. Басараба, С. М. Марчишин, М. В. Кирилив, И. Р. Бекус ТЕРНОПОЛЬСКИЙ ГОСУДАРСТВЕННЫЙ МЕДИЦИНСКИЙ УНИВЕРСИТЕТ ИМЕНИ И. Я. ГОРБАЧЕВСКОГО

\section{АНАЛИЗ ЛИПОФИЛЬНОЙ ФРАКЦИИ ТРАВЫ КОШАЧЬИХ ЛАПОК ДВУДОМНЫХ}

\section{Резюме}

Вступление. Липофильные фракции многих лекарственных растений на сегодня мало изучено, несмотря на то, что они содержат такие важные биологически активные вещества, как хлорофиллы, каротиноиды, токофреролы, фритостеролы, жирные кислоты, фросфролипиды и др., которые, по данным литературы, проявляют репаративную, противовоспалительную, антисептическую, иммуностимулирующую, противоопухолевую активность. Из соединений липофильной природы важное значение имеют каротиноиды и хлорофриллы. Каротиноиды повышают резистентность организма к мутагенам и канцерогенам, уменьшают возрастные дегенеративные изменения в тканях, ингибируют пролифрерацию злокачественных клеток, активируют синтез цитокинов и интерлейкинов, участвуют в регуляции транскрипции генов, а также проявляют иммуномодулирующее действие. Антиоксидантные свойства каротиноидов обусловливают их фротозащитное, радиопротекторное, антимутагенное и антиканцерогенное действие. Хлорофиллы в организме человека способствуют образованию гемоглобина. Их можно применять в медицине как ценное терапевтическое средство, ускоряющее процессы кроветворения. Они влияют на фрормулу крови, а также стабилизируют работу кровеносной системы. Хлорофиллы способны активизировать различные функции организма человека, в частности щитовидной железы, антитоксическую функцию печени, а также являются тонизирующим средством, нормализуют метаболические процессы и повышают иммунитет.

Цель исследования - получить липофильный экстракт травы кошачьих лапок двудомных, изучить его качественный состав и определить количественное содержание каротиноидов и хлорофиллов.

Методы исследования. Липофильную фрракцию травы кошачьих лапок двудомных получали методом исчерпывающего экстрагирования сырья хлороформом в аппарате Сокслета. Полученную липофильную фрракцию использовали для определения хлорофиллов и каротиноидов методом тонкослойной хроматографрии. Количественное их содержание определяли спектрофотометрическим методом. Содержание суммы хлорофриллов определяли при длине волны 670 нм в пересчете на хлорофрилл $A$, каротиноидов - при длине волны 450 нм в пересчете на $\beta$-каротин.

Результаты и обсуждение. Выход липофильной фракции травы кошачьих лапок двудомных в пересчете на абсолютно сухое сырье составил $(6,17 \pm 0,12) \%$. Липофильная фрракция травы кошачьих лапок двудомных - густая маслянистая однородная масса грязно-зеленого цвета с приятным специфическим запахом, не растворяется в воде очищенной $P$ и этаноле $96 \%$, легко растворяется в хлороформе $P$. Содержаниехлорофиллов и каротиноидов в исследуемом экстракте составило $(0,085 \pm 0,003)$ u $(0,029 \pm 0,001) \%$. Содержание хлорофиллов в траве кошачьих лапок двудомных было в 2,9 раза больше, чем каротиноидов.

Выводы. Получена липофильная фрракция травы кошачьих лапок двудомных, выход которой составлял 6,17\%. Определено в ней количественное содержание хлорофриллов и каротиноидов, которое составляло в траве кошачьих лапок двудомных 0,085 и 0,029 \% соответственно.

КЛЮЧЕВЫЕ СЛОВА: кошачьи лапки двудомные; липофильная фракция; каротиноиды; хлорофиллы.

Received 16.01.19

Address for correspondence: S. M. Marchyshyn, I. Horbachevsky Ternopil State Medical University, Maidan Voli 1, Ternopil, 46001, Ukraine, e-mail: marchyshyn@tdmu.edu.ua. 